\title{
PLATO AND ARISTOTLE ON THE DENIAL OF TRAGEDY
}

When Plato's and Aristotle's views on poetry are juxtaposed, it is usually for the purpose of contrast. Nowhere does the contrast seem to be so sharp as in the case of tragedy, by which both philosophers, agreeing in this at least, rightly meant Homer's Iliad as well as the plays of the Attic genre specifically given the name. ${ }^{1}$ While Plato made tragedy the target of his most fervent attacks on poetry, Aristotle devoted the major part of the Poetics to a reconsideration of the genre, in a sympathetic attempt, it is normally agreed, to defend it against Plato's strictures, and to restore to it some degree of valuable independence. The apparently fundamental opposition between the philosophers' responses to tragedy can be regarded as expressive of divergent presuppositions about the status of poetry as a whole in relation to other components of culture: on the one side, the presupposition of Platonic moralism, by which poetry is subjected to judgement in terms of values, both cognitive and moral, which lie outside itself; and, on the other, of Aristotelian formalism, according to which autonomy can be established for poetry by turning the criteria of poetic excellence into standards internal and intrinsic to poetry's own forms. As Aristotle himself puts the point, in one of the Poetics' more suggestive pronouncements, 'correctness in poetry is not the same as correctness in politics or in any other art.'2 Here, as often, an implicit response to Plato can be detected.

In the light of this latter principle, and of other aspects of the treatise, it would be fatuous to deny that in the Poetics Aristotle sometimes presents to us the face of a formalist. What I shall attempt to argue, however, in the later part of this paper, is that behind this appearance there may lie more of a moral and philosophical attitude to tragedy than we are used to discerning there, and that the ostensible contrast between the moralist and the formalist may not after all be as sharp as it at first seems. It is principally for this reason that $I$ have chosen to bring together Plato's and Aristotle's views on tragedy once again, for I want to suggest that while the differences between them are not insignificant, they have been allowed to obscure what may from a certain angle of vision appear to be an affinity. Needless to say, I am not proposing to offer a comprehensive reappraisal of the philosophers' treatments of tragedy. My aim is to focus on the central question of how they responded to tragedy as the medium of a particular mythic presentation of human life, a presentation constructed around a cluster of traditional religious ideas, and consistently enough embodied in tragic poetry from Homer to Euripides, despite 
important differences between individual poets, to constitute a single challenge to the philosophers' views of the world, and especially their beliefs about the relation between virtue and happiness. I should emphasise that it is to the mythic patterns of Greek poetry, and not to any independently defined idea, that I mean the terms 'tragedy' and 'tragic' to refer in all that follows.

Given the nature of the subject, however, my procedure in the two halves of this paper will not be identical. The apparently formalistic character of Aristotle's treatment of poetry obliges me to examine the heart of the theory of tragedy sketched in the Poetics, in order to see whether this theory is really as philosophically neutral as many have believed. In Plato's case I want, and can I think afford, to avoid rehearsing all the central arguments yet again. I intend instead to give some attention to passages which have been largely neglected in discussions of Plato's attitude to tragedy; and by taking a slightly oblique approach to the subject, I hope to be able to point to certain paradoxes which arise in Plato's rejection of the tragic vision.

In the myth of Er which concludes the Republic we are told how, when the moment came for the souls to choose their next existence in the human world, the man who had drawn the first lot rushed forward and selected the life of the greatest tyrant. The folly and greed with which he acted prevented him at first from realising that it was now his destiny ( $\varepsilon\left\{\mu \alpha \rho \mu \varepsilon \dot{\varepsilon} \vee \eta^{3}, 619 \mathrm{cl}\right)$ to eat his own children and to suffer many other terrible things. When the belated recognition of the nature of his choice did come upon him, he broke into gestures and cries of lamentation, "blaming chance and the gods and everything rather than himself' $(619 \mathrm{~b}-\mathrm{c})$. This anonymous figure may on one level be representative of a general kind of moral ignorance and irrationality (we are told that his behaviour was not unique among the souls which Er witnessed, 619dl-3), but he is also specifically reminiscent of the mythical Thyestes, whose life contained the two main details mentioned in the myth - the possession of tyrannical power, at least for part of his life, and the appalling fate of devouring his own children. Thyestes was a typical figure of the type of Greek myth which lent itself to tragic treatment (we know of several plays about him, including works by Sophocles and Euripides ${ }^{4}$ ), a figure whose life embraced the experience both of supreme power and status, but also of a collapse into extreme misfortune. It is not surprising that Thyestes is cited twice, alongside Oedipus and others, in chapter 13 of Aristotle's Poetics, as a paradigmatic subject for the tragic stage. ${ }^{5}$ But it is equally telling that when Plato refers in Book 8 of the Laws to the stories of Thyestes and Oedipus as they are presented in 'all the so-called seriousness of tragedy', as he puts it, he interprets them as instances of the just penalty that has to be paid for a great moral offence. ${ }^{6}$ Although Plato here refers to different details of Thyestes' life, his treatment of him, and even of Oedipus, as a character wholly 
responsible for all that happens in his life, is similar to the portrayal of the quasiThyestean soul in the myth of Er. In both places Plato is faithful to the principle laid down by Socrates in Republic 2, that sufferings such as those of the Pelopidae should be presented as moral tales of just punishment. ${ }^{7}$

Plato could hardly have been unaware of his anonymous figure's resemblance to Thyestes, and the description of the man's self-pitying behaviour after his recognition of his fate is surely designed to recall the critical observations made earlier in Book 10 itself on the emotional and emotive nature of tragic poetry. In both passages we find emphasis placed on the extravagant grief that accompanies, or in the second case anticipates, suffering of an apparently extreme kind; 8 in the one case we are dealing directly, and in the other allusively, with material which Plato considered characteristic of tragic drama and its Homeric prototype. It is for this reason that it is worth asking whether there is anything we can discern in the short passage in the myth of Er which will supplement the case made explicitly in the earlier parts of the book.

Although Plato's anonymous figure evidently and deliberately lacks the stature of a true tragic hero, it is significant, I believe, that his story has been given enough of the lineaments of a tragic myth to make it simultaneously evoke and contradict the shape that might be given to such material by a poet working with traditional religious categories. What Plato does is to dramatise a tension between free human choice and the combined limitations of ignorance, on the chooser's part, and an externally imposed or sustained necessity. ${ }^{9}$ The individual's responsibility seems to be unequivocally stated in the clipped words of the $\pi \rho 0 \varphi$ in $\tau\rceil \varsigma$ who speaks for Lachesis. "A daimon will not be allotted to you; you will choose your daimon.'10

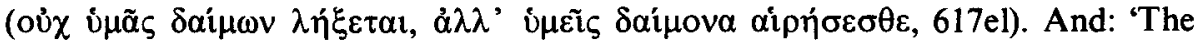

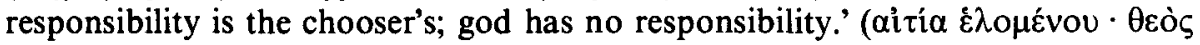
ávaitıos, ib. 4-5). Already here there is a problematic implication. Why, if a free choice is to be made, should the question of a daimon arise at all ${ }^{11}$ ? The paradox later hardens, when all the souls have made their choices and they go before Lachesis herself, who assigns to each of them the daimon which it chose-a daimon to fulfil the choices made (620d6-el). The combined forces of Necessity now fix as a fate, a $\mu$ oi $\rho \alpha,\left(620 \mathrm{e} 4\right.$, cognate with the earlier $\left.\varepsilon i \mu \alpha \rho \mu \varepsilon^{\prime} \vee \eta^{12}\right)$, what was supposed to originate as an autonomous choice. This fact lends an ironic note to the earlier description, which I have already quoted, of the first soul's grief on his realisation of his irrevocable destiny - his complaints against "chance and the gods and everything rather than himself' - an irony which is strengthened by the use of the word $\delta \alpha^{\prime} \mu o v \alpha \varsigma$ in this last phrase.

The irony, though, is double-edged. Plato intends it to operate against the traditional and archaic view of man as only partly in control of his life even in the seeming moments of real freedom. We are meant to be distanced by the moral perspective of the myth from the self-pitying role assumed by the anonymous figure, whose sloughing of responsibility significantly echoes the words of 
Agamemnon in Iliad 19.86-9:

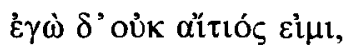

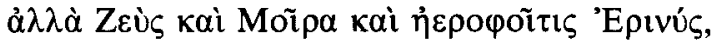

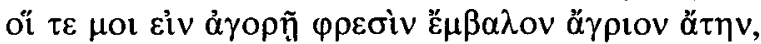

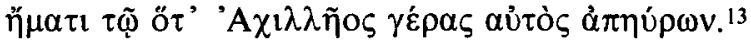

Against this, however, there are disquieting suggestions lurking around Plato's attempt to turn the traditional concepts of $\alpha v \alpha \dot{\gamma} \gamma \eta, \delta \alpha i \mu \omega v, \mu o \tilde{i} \rho \alpha$ and $\varepsilon i \mu \alpha \rho \mu \dot{v} v \eta$ into mythical or symbolic enforcements of the injustice contained within the individual's choice of life. It is precisely because the myth makes so much of $\dot{\alpha} v \alpha \dot{\gamma} \gamma \eta$, as the principle of the framework within which the souls choose and within which their choices are to be fulfilled, that we may have difficulty in understanding Lachesis and her sisters, or the personal daimon assigned to each soul, to be reducible to the forces supposedly implicit in the individual decision and pattern of life. The dramatic frame of Plato's myth leaves the ideas of necessity and destiny with their full traditional potency, yet its overt moral content puts all the responsibility for their particular operation onto the human soul. It is only to be expected that this should leave us with an irresolvable paradox. By trying from within, as it were, to translate potential tragic material into the substance of a moralistic fable, Plato is obliged to give a voice to the tragic outlook - to let it be heard, at least in the background, even at the moment of his own denial of it. In the attempt to use conventional religious categories to dramatise the equation of injustice with unhappiness, an equation which in the Republic and the Laws he says that poets, contrary to much of their existing practice, should be compelled to affirm, ${ }^{14}$ Plato nonetheless leaves the problem of undeserved suffering unresolved at the edge of his picture.

As a final, brief comment on the paradoxical nature of the fate of the first soul in the myth of Er, 1 mention the question of pity, the distinctive tragic emotion. Socrates relates that some of Er's experiences in the other world aroused pity in him (620al). Is the hasty first soul a fitting object of pity? It would surely cut right against the grain not only of the moral of the myth, but also of the Republic's whole idea of justice, to suppose that the quasi-Thyestean figure could be meant to merit any real pity. He is taken to bring his own fate on himself; the cause of it lies in his own soul. His sufferings will be a punishment, and Platonic punishment is good for its subject. But, by the same token, whatever happens to a soul in the world which the myth portrays ought to be an expression of perfect justice. There seems to be little if any place for pity in Plato's universe. ${ }^{15}$ Yet the fact remains that Er feels some, and if we step to one side of the Platonic perspective, we may naturally suppose that he feels some of it for the first soul to choose its next life, for it is made clear that the soul's choice cannot be put down to wickedness, and also that the prospective consequences of the choice, in their extent at least, go far beyond the initial act of volition. This unhappy man's fate is due to his ignorance of the nature of goodness, 
despite his previous existence in a well-governed state; he is hardly comparable to the incurably evil tyrants whose physical punishment was gruesomely described earlier in the myth (615d-616a). ${ }^{16}$ If Er were a good Aristotelian, he might well feel that he had here witnessed a tragic $\alpha \mu \alpha \rho \tau i ́ \alpha$. Yet it is precisely, if ironically, for his $\alpha \mu \alpha \rho \tau i \alpha$ that Thyestes is said to deserve the just punishment of death in the passage from Laws 8 which I cited earlier (p. 50 above). We can at any rate say, I think, that Er's pity is incongruous with the total effect of his story; it is placed within the myth as a symptom of an attitude - an attitude potentially open to tragedy - which the myth as a whole is intended to counteract. Once again, Plato hints at the possibility of tragedy at the very moment of his denial of it, and we shall shortly encounter something similar in one of his greatest expressions of antagonism with the poets, the Phaedo.

I have chosen to give some space to this short passage from the myth of $\mathrm{Er}$ because I believe that in its oblique glance at a pattern of tragic myth, together with the entailed concepts of divine compulsion and destiny, it crystallises one aspect of Plato's challenge to the vision of the poets. Although this challenge must ultimately be regarded as religious and metaphysical, it also centres around the question of human suffering, to which I now turn more specifically. The good man who suffers an apparent misfortune such as the loss of a son will, according to the Platonic Socrates of Republic 10, bear his grief with as much composure and self-discipline as possible. He will indeed, if he is capable of it, not grieve at all (603e). The reasoning part of his soul will tell him that it is not clear that the ordinary view of such things as evils is right, that grief is useless, and that nothing in human life is of

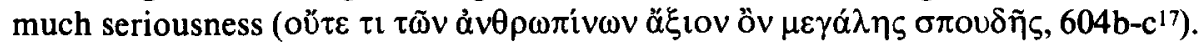
This passage comes from the discussion of dramatic poetry, which Plato here virtually equates with tragedy (he touches on comedy at the end, 606c), so that the bearing of these Platonic attitudes on Greek tragedy is unquestionable. It is usual for treatments of this section of Book 10 to put the main weight on what Socrates says about tragedy's capacity to excite and encourage emotions which are better kept in check: the observation at 606d that poetry waters and nourishes feelings

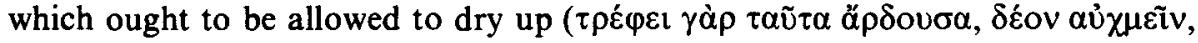
606d4-5) is often rightly picked out as a telling formulation of Plato's objections to the psychological effects of art. But it may be misleading to concentrate too exclusively on the emotions, and to miss what for Plato must be the more fundamental point about the false view of things, the spiritual ignorance, which is supposed to underlie both the nature of tragic plays and the response of audiences to them. Although Plato himself tends to emphasize the symptomatic emotional indiscipline of tragic characters and their audiences ${ }^{18}$, he indicates clearly that this is no matter of mere psychological hygiene, but one part of the soul's failure to see the truth about the good. The reason will tell the soul that life is not worth much in any case. We have heard this asserted before, in Book 6, where Socrates asks: 'If a man has the vision of all time and all being, do you think it is possible that he will 
regard human life as of any real importance?' (486a). This illegitimately rhetorical question rests on the belief that because the body and all that relates to it belongs to a level of existence which passes away, such things can therefore ultimately count for nothing. ${ }^{19}$

It is on the basis of this belief and its metaphysical foundation that Plato is able, in his confrontation with tragedy, to move towards a denial of suffering: not a denial of the limited reality on the corporeal level of the misfortunes which occasion grief, still less of the psychological force of grief and kindred emotions in themselves, but a renunciation of the significance of suffering. For the perfectly good man, it seems clear, there would be no suffering; $\delta v \sigma \tau \cup \chi i \alpha$ would be a purely external way of looking at things which happened to him, and one which could purchase no hold on his reason-governed soul. The good is immune to external change (Rep. 380e-81b). At the opposite pole from this perfect specimen of philosophical truth and goodness stands not the ordinary human being, given though he may be to attachment to this life, but the tragic hero. The major characters of Homeric epic and Attic tragedy represent life lived at its heroic limits, a life which tests, in particular, the limits of suffering; and Plato's opposition to such poetry shows his awareness of this fact. The discussions of poetry in Rep. Books 2-3 and 10 form a continuity on this point, if not on others. In both places general human attitudes to misfortune are challenged through the questioning of poetry's portrayal of such things in the life of heroes. In Book 3, in making precisely the same point as later about the good man's capacity to bear suffering impassively, Plato castigates the Homeric portrayal of Achilles, of Priam, and even of Zeus in his mourning for Sarpedon (387d-388); in Book 10 he contents himself with generic references to the showing of such grief in Homer and tragedy. ${ }^{20}$ The tragic hero differs from the ordinary man in being supposedly great and good, something that Plato acknowledges more than once in both books. ${ }^{21}$ It is this combination of high status and merit, heroic status, with the display of an exceptional vulnerability to

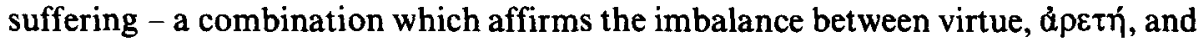
happiness - that makes the tragic hero the antithesis of Plato's good man. And in this connection it is important to notice that in Book 10, at the climax of his attack on poetry, Plato recognises the power of poetry to corrupt, as he puts it, even the best men, apart from a very few (605c6-8): this immediately precedes the reference to tragic images of heroes in sorrow (605c10-d5), and it helps to establish that it is tragedy's assertion of the place of suffering at the heart of the great life which Plato is set on contradicting.

Fervently though this strand of Platonic doctrine is presented, it has to be admitted, I think, that we find some equivocation on the point. Plato's moral idealism cannot be sustained wholly without regard to common experience. Various hints show that the existence of calamities is acknowledged as an inescapable feature of human societies, at least as they are at present organised. There will be no end to evils in the world, Socrates asserts in Rep. 5, until 
philosophers rule it, and the point is repeated in similar words in Book 6.22 It is striking that in criticising the poets' portrayals of the gods in Rep. 2 Socrates concedes that human life contains more evil than good, but his concern is to deny that the evil can be attributed to divine causes, as in the famous Iliadic passage about Zeus's jars. ${ }^{23}$ But does Plato purport to claim that suffering of misfortune would disappear if society were radically reformed along his ideal lines? Certainly not in the envisaged society of the Laws, where the possible impact of $\tau \dot{v} \chi \eta$ and $\delta v \sigma \tau u \chi i \alpha$ is occasionally acknowledged. ${ }^{24}$ In Rep. 3 Socrates seems to contemplate the possibility of a type of serious drama in which the good man's ability to withstand suffering, and thereby to reduce it ideally to insignificance, would provide the subject matter. The issue comes up in the section of the dialogue on musical modes, where Socrates enquires about a mode which could be used to accompany the artistic representation of fortitude in the face of danger, death or other misfortune (399a-c). It might be possible to interpret this as a transitional artform, a kind of reformed tragedy, on the road to the realisation of the perfect society; but it seems doubtful whether Plato's idealism stretched to the belief that all ostensible suffering could ever be eliminated from life, whatever the organisation of society, and so we find him, for example, referring to the fact that in the perfect state people will have a strongly unified sense of the misfortunes of individual citizens (463e). There might always, then, it seems, be a role for art to dramatise the good man's courageous resistance to the material sufferings of earthly existence. It is an interesting question to ask just what Plato envisaged the nature of such art as being. It could surely not coincide with existing scenes of tragic resilience such as, say, Priam's visit to his son's killer in the Iliad, or Heracles' final acceptance of his fate in Euripides' Heracles, since in these and many other instances there is, quite apart from the juxtaposition with elements of naked grief and self-pity, no sense that the given misfortune can be reduced in significance, certainly not by comparison with some other-worldly scheme of things in which the corporeal will cease to matter. The Platonic 'tragedy', if one may call it that (see below p. 58 on Laws 817), would presumably turn us rather in the direction of complete spiritual control over the ordinary power of suffering. Could it do so, however, without allowing full dramatic weight to this power?

This question is certainly worth asking, for we have available a more direct approach to it than the brief and hypothetical passage from the Republic allows. We can look instead to the Phaedo, a work which ought to provide an appropriate test of Plato's attitudes to tragedy. The situation in the dialogue is one which would be susceptible to tragic treatment by someone who shared Plato's estimation of Socrates but not his metaphysics. In more than one passage of the Republic and the Law's Plato seems to take it that the typical tragedy centres around an individual, a great or supposedly great man. Whether or not Socrates' life would meet the criteria of a heroic existence, its nature in Plato's eyes was such as to make his death a challenge to the philosopher's views. Could Socrates' death be in any sense, for 
Plato, a tragedy - an appalling and paradigmatic case of philosophy's rejection by the world, representative of some ineradicable flaw in things, and an overwhelming personal loss for those who lived around Socrates? If we remember the passages in the Republic where it is the loss of a pì os, and the grief-laden reaction to such loss, which is held up as the archetypal subject of tragic poetry, then it becomes more than a matter of biographical curiosity to ask whether Plato allowed the force and propriety of grief as a reaction to Socrates' execution. I do not claim to have a simple answer to this question, partly because it might reasonably be thought that only Plato's work as a whole could furnish one. But it seems appropriate to interrogate particularly the work in which he comes closest to Socrates' death, and also closest to the type of philosophical 'tragedy' which he makes Socrates himself envisage in the Republic.

There is no doubt that on one level, and perhaps the most important level, the Phaedo is designed not just to challenge but to rebut any simple view of Socrates' death as a tragic event, and it is therefore at least misleading to observe without qualification, as Jowett does, that 'the Phaedo is the tragedy of which Socrates is the protagonist'. ${ }^{25}$ It is unnecessary to show in detail how the dialogue's whole argument, with its strong emphasis on the necessity for the philosophical life of the soul's disentanglement from the concerns of the body (death included), and its conviction of the immortality of the former, gives voice to a rejection of the possibility of the just man's suffering. It is important to grasp that, after all, Plato could have held most if not all of his metaphysical beliefs without denying the force and significance of misfortune in the world of the flesh; there is more than one conceivable way in which he might have endowed the good man's grief with spiritual reality, just as it supposedly is in some strands of the Christian tradition. ${ }^{26}$ Instead, he offers an apparently unqualified renunciation - so strong, indeed, as to suggest, and in the case of Socrates to demonstrate dramatically, that in a certain sort of life, the life of philosophical perfection, equivalent to the heroic life of tragedy, 'suffering' literally loses its meaning.

The argumentative and dramatic repudiation of suffering in the Phaedo at first looks so determined that we might well conclude that Plato has gone even beyond the type of work which Socrates imagines in Rep. 3: it seems that we are dealing not with the spiritual mastery of suffering, but with its obliteration from the good man's scheme of values. Yet if this is so, it has to be recognised that Plato at least allows elements of a different view of Socrates' death to be glimpsed in the course of the dialogue. He does this partly on the level of argument, by giving Simmias and Cebes doubts about the immortality of the soul, doubts which communicate themselves to the rest of the company and concern future as well as already stated considerations on the subject. ${ }^{27}$ To the extent that such doubts might be taken seriously, the possibility opens up of seeing the execution of Socrates as an unredeemed waste of his life's value. More pointed, though, are the dramatic indications of what can be regarded, by reference to the attacks on the genre in the Republic, as typical tragic 
behaviour. The first of these is the dismissal of Xanthippe near the beginning of the piece (60a), echoed by a second dismissal of the women near the end of the dialogue (116b). When Phaedo and his companions entered Socrates' cell on the day destined for his execution, Xanthippe let out a cry of grief and uttered a lament for the fact that this was to be the last time her husband and his friends would see one another, a lament for which there are tragic parallels, and one which in its selfconsciousness might be thought to be particularly appropriate to drama. ${ }^{28}$ Socrates gives simple orders for Xanthippe to be taken away, leaving scholars to speculate about what Plato might here be intimating about relations between husband and wife. But the moment should not be given biographical weight in that crude way; it is primarily a gesture which expresses Socrates' renunciation of the ties of life and of the emotions which the valuing of these ties leads to. ${ }^{29}$ Later in the dialogue, in the closing minutes of Socrates' life, Plato again refuses to allow any acknowledgement of suffering on the philosopher's part, and he does so here by more evidently dramatising a refusal of the conventions of mourning which he elsewhere identifies so closely with tragedy. ${ }^{30}$ The contrast between his portrayal of Socrates and the characteristic Homeric-cum-tragic treatment of the end of a hero is suggested by Socrates' own words at $115 \mathrm{a}$, where he ironically borrows the language of the ơvì $\rho$

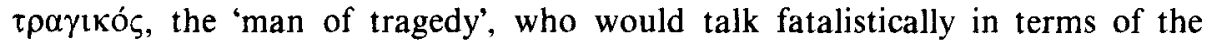
summoning of destiny ( $\varepsilon^{\prime} \mu \alpha \rho \mu \varepsilon v \eta$, the word also used in the myth of Er). ${ }^{31}$ Socrates thus refuses the posture of the self-pitying hero as humorously but resolutely as he does in the Apology, where he refers to and spurns the forensic convention of an appeal for mercy as the behaviour of one 'staging a pitiful drama' ( $0 \tilde{v} \tau \dot{\alpha} \hat{\varepsilon} \lambda \varepsilon i v \grave{\alpha}$

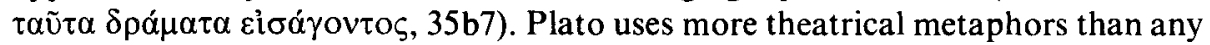
other classical Greek author, and this fact reflects his consciousness of his own dramatic methods. ${ }^{32}$

Set against Socrates' capacity for impassive acceptance of his death, and even for ironic humour, are the impulsive lamentations of Phaedo, A pollodorus and the rest of those present. Phaedo weeps, on his own later admission, not for Socrates but for himself $(117 \mathrm{c})$. This helps to bring out an implicit connection with Plato's attacks on tragedy in the Republic, for what we are shown here is the self-regarding grief of one too attached to life, one whose emotions are incapable of suppression (117c-d). But there is a striking paradox here. Plato is himself dramatically portraying something akin to the type of behaviour which he elsewhere rebukes the tragic poets for showing. It is true, of course, that Phaedo and the rest are presumably not to be treated as paragons of virtue, and their display of sorrow is therefore intelligible as a mark of inadequacy, in contrast to Socrates' perfect self-control. But the companions of Socrates are moved by a genuine and admirable love of him and this seems to be something which Plato's whole enterprise presupposes as commendable. And however much the emotion of the closing scene is subordinated to the central religious arguments of the dialogue, the fact remains that Plato's dramatic skills are used at the end to lend moving force to the view which Socrates' 
companions naturally take of their master's death. It is not that this final scene vindicates the tragic perspective which has already been so strongly denied by Socrates himself; but it does momentarily seem to offer it to the reader, and I find it hard to conclude that Plato was unconscious of this effect. ${ }^{33}$ Plato the tragedian has not been wholly suppressed by Plato the metaphysician.

I have tried briefly to suggest that the Phaedo stands as, among other things, a Platonic attempt to carry out the scheme of Rep. 3 and to dramatise the virtuous man's defeat of suffering and grief, but that this attempt involves Plato in the perhaps inescapable paradox that his own work includes and effectively employs some of the very features of tragedy against which his philosophical thrust is directed, analogously to the way in which the myth of Er uses traditional religious categories in asserting the individual's responsibility. In both these respects the Phaedo gives vivid form to the idea later found in the Laws that 'the finest and best life is the truest tragedy' $(817 \mathrm{~b})$, in a passage which sets up the philosophical life, in the boldest and most provocative of Plato's dramatic metaphors, as an alternative to the life of the tragic hero, and which makes the writing of philosophy an alternative to the writing of tragic drama. This late passage is in a sense prefigured, I think, in the Phaedo itself, in Socrates' famous description of philosophy as 'the

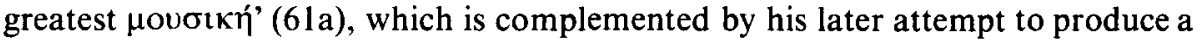
philosophical $\mu \tilde{v} \theta 0 \varsigma$ to rival that of the poets. ${ }^{34}$ What we have in both places is explicit testimony to the Platonic sense of being involved in a direct conflict between philosophy and poetry, (the 'long-standing quarrel', Rep. 607b), and the Phaedo as a whole can be read as perhaps the most deliberate of Plato's attempts to sustain that rivalry against what he rightly saw to be a coherent alternative to his own philosophy, the tragic poets' view of the world. Whatever the truth of the story that Plato composed tragedies as a young man, we get glimpses as early as the Apology of an interest in both measuring and contrasting Socrates with the standards of mythical heroism, not only in the passage where Socrates cites Achilles and the other 'demigods' who fought at Troy for the virtuous fearlessness with which they faced death ( $28 \mathrm{c}-\mathrm{d})$, but also in the closing section of the piece, where Socrates imagines himself discoursing in Hades with 'other victims of unjust verdicts' such as Palamedes and Ajax (41b), both of them standard tragic figures. As later in the Phaedo, Plato simultaneously and wryly both evokes a heroic model for comparison, and yet also uses it as a foil to Socrates, since the latter's anticipation of taking pleasure in conversing with Palamedes and Ajax acts as an expression of his refusal to regard his own death as tragic. ${ }^{35}$ Here as in many later passages we witness, I think, Plato's fascination with tragic myth, as well as his rejection of it.

In moving from the philosophical drama and irony of Plato's dialogues to the 
rather cold and dry world of Aristotle's treatise on poetry, we experience an obviously sharp shift in style, tone and apparent sympathies. Yet it has long been recognised that Aristotle carries over much from Plato's treatment of poetry, subtly altering what he borrows at many points. ${ }^{36}$ On the central issue of their attitudes to tragedy, however, there is a modern consensus that the two philosophers diverged radically. It seems, indeed, that Aristotle did not simply fail to accept Plato's religious and metaphysical objections to tragedy, but that he even considered matters of this sort to be wholly irrelevant to the understanding of poetry. It is certainly remarkable (and, I shall argue, significant) that the Poetics largely neglects tragedy's religious dimension; and when the subject is touched on, in ch. 25 , no-one who is reading the book with the Platonic background in mind can fail to find arresting the passage where Aristotle effectively dismisses the whole tradition of philosophical complaints about poetry's portrayal of the divine, identified by reference to Xenophanes. The dismissal is couched in one of those Aristotelian laconicisms so typical of the Poetics: 'Perhaps it is neither moral nor true to say such things about the gods, and perhaps Xenophanes was right; but, anyway, men do say these things.' (1460b36f.) This is actually offered as the solution of a 'problem'. As Lucas aptly comments, 'an answer less likely to satisfy Plato would be hard to imagine.'37

If this passage were taken to summarise the whole of Aristotle's view of the moral and religious side of poetry, particularly tragedy, it would evidently be futile to ask of the Poetics the question which has been the motive of my consideration of parts of Plato's critique of poetry, namely how does it confront tragedy as the medium of a specific vision of life, at least the limits of life represented by the heroic. But it is my contention that to accept such a conclusion would be premature, and that we need instead to scrutinise the apparently formal doctrines of the Poetics to see whether they may not imply more of a philosophical stance than at first sight looks likely.

A preliminary stage in the argument can be based on Aristotle's concept of a poetic $\mu \tilde{v} \theta 0 \varsigma$. The term $\mu \tilde{v} \theta \circ \varsigma$, together with a group of cognates, is found frequently in Plato's discussions of poetry. ${ }^{38}$ For Plato, as for Aristotle, $\mu \tilde{0} \theta \circ$ o is the essence of poetry. Plato, however, consistently treats a $\mu \tilde{v} \theta \circ \zeta$ as identical to its narrative or dramatic content; he takes it to embody a proposition or set of propositions (usually false propositions), or as equivalent to a picture (which he also treats as having a quasi-propositional status). A story is thus always a story about something putatively outside itself, and Plato regards a judgement on a story's truth or falsehood as the proper cognitive reaction to it. Because $\mu \tilde{v} \theta 0$ are assumed to present propositions about the world, moral assessments of their educational and cultural use naturally arise. Aristotle takes over the term $\mu \tilde{v} \theta \circ \varsigma$ but makes of it a quasi-technical term, designating the formal product of the poet's $\tau \dot{\varepsilon} \chi \vee \eta$. He devotes the core of his analysis of tragedy, chs. 6-14, to an elaborate consideration of the internal relations of the $\mu \tilde{v} \theta 0 \varsigma$ : its unity and proportion, its 
self-contained quality, and its various structural constituents, such as 'reversal' and dénouement. It is to a large extent in and because of their divergent concepts of $\mu \tilde{\theta} \theta \circ \varsigma$ that Plato and Aristotle are believed to take wholly incompatible views of the moral and religious content and status of poetry. The Poetics ostensibly proceeds, in those central chapters, it is commonly agreed, as if the propositional status of a $\mu \tilde{v} \theta \circ \varsigma$ had been discarded, to be replaced by a purely aesthetic notion of form.

To demonstrate the weaknesses of this common view requires a detailed argument which cannot be offered here, but some objections may be briefly noted. Much interpretation of the Poetics has suffered from the application of an extreme and falsifying polarity, of the kind which I characterised in my introduction, between moralistic and aestheticist views of poetry and art. Although such a polarity has its roots in ancient criticism, it is not one to which the Poetics is straightforwardly susceptible, yet it has been employed both to support the didactic reading of the treatise which was standard in the Renaissance and later, and to vindicate the interpretation of its doctrines as purely formal which has been dominant in modern times, under the influence of the strong post-Enlightenment separation of moral and aesthetic values. In Aristotle's case the prejudicial polarity needs to be replaced by a more subtle framework which takes account of the philosopher's own conception of the relation between poetry and other forms of activity and understanding. ${ }^{39} \mathrm{I}$ must restrict myself in the present context to a reference to the indication given in Poetics 9 of a degree of kinship between poetry and philosophy - a passage which many (mostly philosophers) have tried to play down, but which remains clear evidence, supported elsewhere, of Aristotle's belief in the cognitive value of poetry, and is in itself sufficient to throw aestheticist interpretations of the treatise into grave doubt. Outright formalism is, in fact, inconceivable in a theory of poetry which relies as heavily as does the Poetics on the central concept of mimesis. A poetic $\mu \tilde{v} \theta 0 \varsigma$ may need to be analysed and judged in terms of categories and criteria which respect its status as an independent art, but independence from wholly external standards need not, and given mimesis cannot, entail complete autonomy or isolation. It is a more subtle relation between art and experience than the moralism-aestheticism dichotomy allows for that Aristotle acknowledges, among other ways, by his attribution to poetry of a concern with tò $\kappa \alpha \theta$ ó $\lambda$ ov, the 'universals' which enable it to aspire to the condition, if not the methods, of philosophy. And it is the notion of a tragic $\mu \tilde{v} \theta 0 \zeta$ as the embodiment, or enactment, of $\tau \dot{\alpha} \kappa \alpha \theta$ ó $\lambda$ ov which reduces, without altogether eliminating, the apparent discrepancy between Plato's and Aristotle's views of the status of poetry. The false propositional relation of poetic $\mu \tilde{v} \theta$ o to particulars, which Plato had castigated, is converted by Aristotle into a potentially close correspondence between the $\mu \tilde{v} \theta 0 \varsigma$ and 'universals'.

But the argument is still far from yielding an answer to the question whether a particular ethical point of view can be discerned in Aristotle's theory of tragedy. In order to come closer to this, we need to focus sharply on the nature of the tragic 
$\mu \tilde{\theta} \theta \circ$ sosited in the Poetics, and to see that the one essential element in it is a 'change of fortune'. About the direction of the change - whether it should be into misfortune, or out of misfortune - the Poetics significantly vacillates; ${ }^{40}$ but some sort of transformation ( $\mu \varepsilon \tau \alpha \dot{\beta} \beta \sigma i \varsigma$ or $\mu \varepsilon \tau \alpha \beta o \lambda \eta \dot{)}$ ) is repeatedly presumed, and from it we can derive much else - including the tragic emotions, and the nature of the 'complex' plot - in the theory. The distinctive themes of tragedy are therefore to be

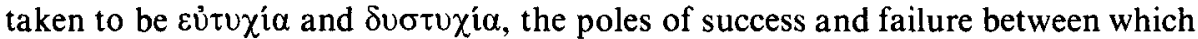
the characters of tragedy move. I do not want immediately to confront the old issue of why Aristotle apparently changes his mind between chs. 13 and 14 of the Poetics about the direction of the change of fortune, though I shall later come back to this. Instead, I want to take the two different types of tragic configuration, as they are specified in these chapters, and to ask of them in turn how they are related to the character of traditional tragic myth.

I propose to take chapter 14 first, since in itself it seems to me less problematic. It is important to note that though the argument of this chapter leads Aristotle to a preference for a play in which an extreme of suffering is threatened but averted, he does not relax his primary requirement that the play should elicit fear and pity; indeed, he reemphasises it at the start of this section (1453b11-15). This is a little paradoxical, since the emotions of pity and fear have been explained as responses to suffering (1453a4-6), but it does make clear that for Aristotle the plot in which, say, an appalling killing within the family is narrowly avoided need not differ in its emotional quality from one in which the same event does take place. ${ }^{41}$ The same sensitivities will be touched in the audience by the prospect as by the actual occurrence. This is important, and is related to Aristotle's understanding of the tragic emotions; but what it does not explain is why a critic whose conception of tragedy revolves around the emotions of pity and fear should have, at any stage, preferred such works to those in which pitiful and terrible events were fully enacted. I am not now simply referring to the contradictions between chapters 13 and 14 , for even if Aristotle had not left conflicting judgements on this point, we would still have to account for the idea that the drama of averted catastrophe could satisfy better than any other the tragic requirement of a pitiful and fearful change of fortune. It is pertinent but insufficient to show that such drama could make full use

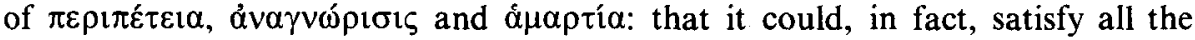
requirements of the complex plot. ${ }^{42}$ It remains to find a consideration which could induce a preference, within the terms of Aristotle's theory, for the Iphigeneia in Tauris over the Oedipus Tyrannus.

When in the course of ch. 14 Aristotle describes the type of plot in which a terrible act, about to be committed in ignorance, is prevented by a scene of 'recognition', the

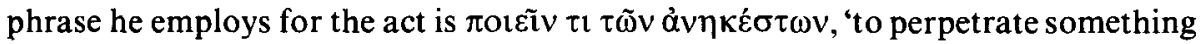

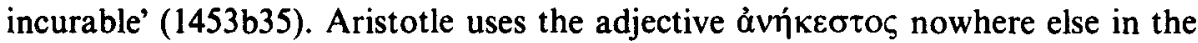
Poetics, and only once outside it (Rhet. 2.23, 1399b4), but it is an apt word for the ultimates of suffering and evil, and is found with this force in a variety of Greek 
authors. ${ }^{43}$ It is ironic that the word should occur just here within the Poetics, since it can only apply proleptically to the case of an averted misfortune. Aristotle's averted catastrophe simply is not, in the end, a catastrophe; and if the requisite tragic emotions are to be aroused by undeserved suffering, then while the prospect of such suffering may successfully elicit them, it cannot do so in quite the same way as the actuality. This is not a matter of a calculable difference between the appropriate emotional response in the two cases; one can say only that the enacted tragedy subsumes and goes beyond the prospective but prevented tragedy. Nor, of course, is the matter purely one of emotion: the tragic emotions are related, on Aristotle's own theory, to the recognition of a particular pattern of action..$^{44}$ What the type of drama preferred in Poetics ch. 14 lacks is precisely the experience of the 'incurable', the absolute tragedy, the collapse into $\delta v \sigma \tau u \chi i \alpha$ which can never be revoked. But it is just this extreme degree on the scale of unhappiness which characterises many of the major tragic myths and dramas from Homer onwards. It is the kind of suffering which, as Aristotle himself observes of the misfortune of Priam in a passage from E.N. 1 to which I shall be returning, makes any possibility of happiness inconceivable $(1100 \mathrm{a} 8-9,1.9 .11)$. Even if we can allow the title of tragedy, then, to the drama of averted misfortune - as on one level we must - it cannot be tragedy of the same intensity, or with the same implications, as this: for the aversion of what would otherwise have been incurable does not eliminate the possibility of $\varepsilon v \delta \delta \alpha \mu$ ovía, in either the traditional or the Aristotelian sense. I think we are therefore justified in regarding Poetics 14 as a prescription, in dramatic terms, for the avoidance of extreme tragedy. ${ }^{45}$ But before attempting to say more precisely what this might signify, we need first to turn attention to the preceding chapter of the Poetics, since it might be thought to be the corollary of what I have just claimed that we do there find an acceptance of ultimate $\delta v \sigma \tau \chi \chi i \alpha$.

As a brief prelude to consideration of ch. 13, I need to say something about

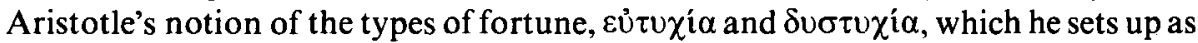
the poles of tragic experience, and which for him represent above all the fabric of status, the material and social 'external goods'. ${ }^{46}$ Plato's attacks on tragedy in Rep. 2-3 and 10 had similarly centred on the idea of a change of fortune, a fall into $\delta v \sigma \tau u \chi i \alpha$, or rather on the common interpretation of certain experiences in these terms. Working from the premise that $\delta v \sigma \tau u \chi i \alpha$ was a misconception either on the level of causality (as with the hasty soul's attempt to deny responsibility for its own evils) or on the level of moral evaluation (since bodily 'suffering' could hardly be regarded as a real evil, if properly viewed), Plato was able to suggest that the portrayal of apparent misfortune should be either eliminated from poetry altogether, or else only allowed on the condition that it should be used to show the virtuous man's superiority over it. Aristotle's mature views on the relation between body and soul led to a much more pragmatic conception of the connections between virtue and corporeal experience, and enabled him to accept that $\varepsilon v \delta \delta \alpha u$ oví $\alpha$ might be to some extent dependent on the material circumstances in 
which a life is lived. I quoted above the passage from E.N. 1 where Aristotle comments on the destruction of Priam's happiness by his tragic misfortune (his

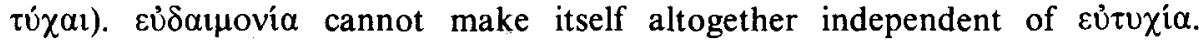

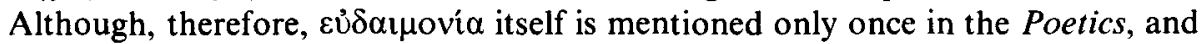
that in a passage which may be spurious and is certainly problematic, ${ }^{47}$ it is reasonable to infer from Aristotle's choice of an example from poetic myth in E.N.

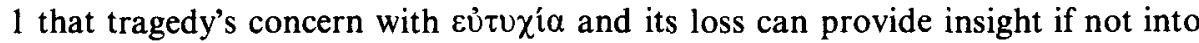
happiness itself, then at least into the relation of happiness to its material circumstances: the same potentially tragic relation which Plato set himself to deny. Yet it is pertinent to the argument $I$ wish to put forward to note that in this same

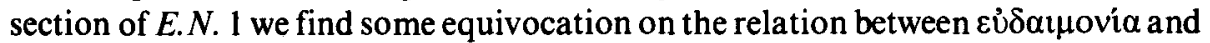

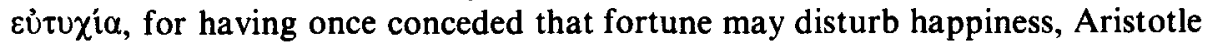
comes back to the question in order to emphasise, in Platonic fashion, the ability of the good man to endure misfortune without diminution of his happiness. ${ }^{48}$

Even if, then, Aristotle's philosophy did allow him to remain open to the force of a type of tragedy whose meaning Plato could not countenance, it still remains to be asked whether in his prescription for the best tragedy, as he conceives of it in Poetics 13, it is this extreme case of .vulnerability to misfortune which he has in mind. An immediate and affirmative answer might seem to be provided by the fact that Aristotle here cites the tragedy of Oedipus, by which he is likely as elsewhere to mean Sophocles' O.T.; and if we were to set up a paradigm of Greek tragic myth, we could hardly exclude Sophocles' Oedipus from it. But such an answer would be unsatisfactory, since it fails to take into account the interpretation of the Oedipus myth (as of other myths) implied by Aristotle's use of the term $\alpha \mu \alpha \rho \tau i \alpha$. The mere mention of this term would justifiably arouse a sense of impending longueur at the prospect of yet another reinterpretation of it, but that is not exactly what I want to offer. My concern is primarily with the negative implications of Aristotle's use of $\dot{\alpha} \mu \alpha \rho \tau i \alpha$, which is hardly an inappropriate way of looking at its place in the theory, since its appearance in Poetics 13 is as part of the conclusion to a negative train of thought, whereby a process of exclusion yields what 1 take to be a far from sharply defined notion of a remaining area of tragic possibility. As Aristotle says, formulating his plot-pattern according to a putative central figure, 'it is the man in between these who is left' (1453a7), which I believe means that Aristotle's ideal concerns the type of hero (and tragic plot) who avoids the objections made against other types. It is therefore important to ask just what Aristotle has discarded in his quest for the best type of tragedy.

For my present purposes the two significant exclusions are as follows (there are others which do not bear on my argument):

i. the downfall of the man who is $\dot{\varepsilon} \pi \varepsilon 1 \kappa \eta \dot{s}$ (1452b 34-6).

ii. the downfall of the (less than perfectly) good man for some reason beyond his control. 
The second of these possibilities is not as such mentioned in Poetics 13, but I suggest that it is nonetheless being excluded (or suppressed). Moreover, although there is a difference of moral degree between the two cases I have posited, they have something important in common. The given reason for Aristotle's rejection of the

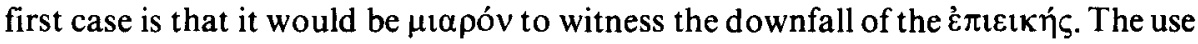
of such a strong term of disapprobation (one which Aristotle uses nowhere outside the Poetics) in itself justifies us in supposing that he must have in mind a man of exceptional or perfect virtue, ${ }^{49}$ and it follows from this that the only conceivable cause of such a downfall, in Aristotle's scheme, would be an $\dot{\alpha} \tau \dot{v} \chi \eta \mu \alpha$, something for which the victim could in no degree be held responsible. ${ }^{50}$ If this is correct, then the two types of tragic pattern which I have mentioned have in common the exclusion of chance or the external impingement of misfortune. This makes good sense as an antithesis to $\alpha \mu \alpha \rho$ ría, which suggests, however loosely, an action originating with the person who suffers its unforeseen or unintended consequences - an agent-centred concept, in other words. These two points, one positive and one negative, support the conclusion that Aristotle did not judge that the best type of tragedy should deal with suffering that strikes a man down from outside.

It is possible to discern here grounds for my contention that there is an affinity between Aristotle's theory of tragedy and one of the central Platonic objections to the genre, since in both cases we find an aversion from the stark tragedy of fate, chance, and - it must now be added - divine causation. The point becomes clearer if we reintroduce into the argument a factor which I mentioned earlier in the paper, the Poetics' neglect of the religious dimension of Greek tragedy. If it is true that Aristotle intends to preclude chance from the best tragic plot (and there are further considerations which support the claim), then this must be brought into relation with his disregard for the theology of tragic myth, since within the world of this myth 'chance' ( $\tau \dot{\chi} \chi \eta)$ has a religious status. Traditional Greek ways of thinking, as Aristotle himself seems to acknowledge elsewhere, did not systematically distinguish between divine causation and the workings of $\tau \dot{\chi} \chi \eta .{ }^{51}$ In this context tú $\chi \eta$ is a word of varied usage, quite capable of subsuming the forces of gods and fate; it is perhaps the word most simply expressive of the fatalism of Greek tragedy and its mythic material, since it has the widest applicability to situations in which what happens is conceived to have been inescapable and externally determined. It consequently amounts to much the same thing for Aristotle to eliminate either chance or divine causation from his ideal tragic plot. Either source of misfortune (or even of good fortune) would be equally hard to reconcile with the conception of tragedy as a genre which by its dramatisation of certain kinds of human action could embody general truths ( $\tau \alpha \dot{\alpha} \kappa \alpha \theta$ ó $\lambda$ ov), akin to those of philosophy. Although, as we have seen, Aristotle allowed popular religious attitudes to figure in ch. 25 as the solution to a general philosophical criticism of poetry, this is a very different matter from allowing such attitudes to determine the essence of the genre.

I promised earlier to avoid a full discussion of $\alpha \mu \alpha \rho \tau i \alpha$, but I ought to indicate 
very summarily here how I think it fits into my case. I take $\alpha \mu \alpha \rho \tau i \alpha$ to be part of Aristotle's enterprise of producing a secular theory of Greek tragedy, and to stand as a philosophical attempt to reconcile the need for suitable tragic material (awesome transformations of fortune) with a view of human experience from which the capricious and the mysterious are to be excluded. $\alpha \mu \alpha \rho \tau i \alpha$ locates the tragic action purely on the scale of moral intention and responsibility; it ignores the religious dimension of the world-view embodied in tragic myth. If, as we must assume, the concept of $\alpha \mu \alpha \rho \tau i \alpha$ is consistent with the general thrust of the Poetics, then it needs to conform to the fundamental requirement of necessity or probability, without which the theory would not cohere. ${ }^{52} \dot{\alpha} \mu \alpha \rho \tau i \alpha$ thus becomes the means of making catastrophe intelligible, but it does so, I would maintain, only at the price of much of what makes existing Greek tragedy distinctive, which includes the sense that the extreme tragedy need not, and perhaps could not, be fully comprehensible.

It may be illuminating now to cast a second glance at ch. 14 of the Poetics. I noted earlier that though there are obvious discrepancies between this and the preceding chapter, there are also shared assumptions, one of which is the possible operation, or even the necessity, of $\dot{\alpha} \mu \alpha \rho \tau i \alpha$ in the ideal plots of both chapters. In ch. 14 Aristotle envisages a plot of much the same nature as in ch. 13, involving an error which leads towards some extreme $\delta v \sigma \tau v \chi i \alpha$ between pí $\lambda o 1$, the crucial qualification being now added that we should stop short of the misfortune itself. There is really not so much separating these two ideal $\mu \tilde{v} \theta 0 \mathrm{r}$ once one sees that for Aristotle both represent tragedies which are located in and caused by human ignorance or fallibility of some kind. If in the case of the first type, the change of fortune is intelligible because attributable to a o $\alpha \mu \alpha \tau^{\prime} \alpha$, then our understanding of such things will be equally confirmed by the second type of plot, in which the recognition of what was previously mistaken is brought about before it leads to 'incurable' suffering. If Aristotle's emphasis is seen to fall throughout on the rational understanding of why tragedies come about, then ch. 14 does not involve an alien and surprising line of thought, but an extension of the preceding argument; and its endorsement of plays of averted catastrophe can be regarded as the fulfilment of the aim of locating tragedy's causes firmly within the realm of human action and fallibility. The experience of prospective misfortune is sufficient to allow the conditions and causes of $\delta v \sigma \tau u \chi i \alpha$ to come within the range of intelligibility, without the need for a display of 'incurable' suffering. Moreover, we can see that in the case of averted catastrophe Aristotle is just as likely as in ch. 13 to disregard the part played by divine causation in actual tragic $\mu \tilde{v} \theta 0$. This is indirectly illustrated later in the Poetics, when in ch. 17 we are offered a summary of the $\mu \tilde{\nu} \theta \circ \zeta$ of Euripides' I.T. The I.T. is one of the plays which embody the averted catastrophe ideal, and it is worth saying that no tragedy is cited in the Poetics with more approval, a fact which the platitude about Aristotle's esteem for the O.T. is too often allowed to obscure. ${ }^{53}$ It is striking that in his synopsis of the plot Aristotle 
omits most of the play's religious dimension, and asserts misleadingly that Apollo's part in Orestes' mission is 'outside the $\mu \tilde{v} \theta 0 \zeta^{\prime}$ ' (1455b7-8).54 This is a telling redefinition of the play in such a way as to leave the foreground of supposedly probable human action intact, but without the divine background which provides the indispensable explanation of events. The secularisation, or rationalisation, is effected, as with much later Euripidean criticism, not by the playwright but by the critic.

Any attempt at an economical interpretation of Poetics 13 and 14, it has to be admitted, will be open to objection and qualification, since Aristotle's train of thought in these sections is simply not of the kind to yield to definitive solutions - a point which particularly needs to be urged against many treatments of the $\alpha \mu \alpha \rho \tau i \alpha$ problem. What I have offered does not, in any case, purport to be a complete reading of these two chapters. I have tried to ask of each of them just one question: what does it imply about the essential pattern of the tragic change of fortune. The answers I have sketched have at least the merit that they bring the two chapters into a closer relation than many critics have been able to discern, and that they allow us to dispense with such hypotheses as that Aristotle forgot himself, or had declined into senile sentimentality, when he set down the views contained in chapter 14 . There is, in fact, no good reason for the common assumption that chapter 13 represents the authoritative statement of the theory, while chapter 14 can be regarded as necessarily secondary and aberrant. I suggest, in short, that Aristotle's overriding interest is in tragic plots whose pattern of causation is susceptible to rational understanding; tragedy's finest material is conceived of as the pathology of human fallibility. Understanding, where ethical action is concerned, may imply that in principle things might have been effected otherwise, that they might have been controlled so as to avoid misfortune. This is evidently so with the type of plot recommended in chapter 14 , where the potentiality of preventing disaster is seen to be realised, yet without, it is supposed, reducing the force of the distinctive tragic experience. In these terms, there is a reassuring element in Aristotle's reflections on tragedy: we sense an underlying conviction that, in a heightened world from which the 'irrational' is excluded, 55 tragedy at least lies within the limits of human intelligibility. If Homeric and Attic tragedy may sometimes seem to embody an awareness precisely of the limits of human comprehension, there is no trace of this in the Poetics. Aristotle himself was certainly able to see that a preference for a particular kind of tragic plot might be based on a desire to discover a basic moral acceptability in the genre, since in chapter 13 he refers to the 'weakness' of audiences who appreciate best the type of play in which poetic justice is achieved, both good and bad getting their deserts (1453a30-35). Aristotle wants nothing so straightforward or emotionally simple, but in a more subtle way, if my argument is right, his own theory is designed to eliminate from tragedy, or to redefine within it, some of those events with which our moral hopes and expectations cannot easily cope. The roots of this attitude go deep in Aristotle's thinking, and I believe that the 
Poetics' scheme of tragedy may be one reflection of a more general tendency in his philosophy which has recently been described as a 'perception of conflict as something to be avoided or managed'. ${ }^{56}$ In making such a claim I should emphasise that I am not attempting to convict Aristotle of a misunderstanding, but of a philosophical reinterpretation of tragedy.

Plato and Aristotle both believed, though with different emphases, in a strong connection between virtue and happiness. One source of conflict between their views and the mythic world of tragedy (Homeric epic included) was a discrepancy in

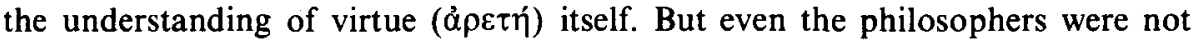
unaffected by the traditional conception of heroism, and their own ethical ideals show a certain affinity with it in the value which they attach to such features as courage and single-minded independence. Yet this degree of common ground may only have thrown into relief the fundamental difference between tragedy and the philosophers' ethical systems, for tragedy typically pictured a world in which the relation of virtue to happiness is far from secure, and perhaps even, at the heroic extreme, a hopeless illusion. ${ }^{57}$ Plato's sense of this contradiction was acute, and provided one of the chief motivations behind his attack on tragedy, though I tried earlier to suggest that he saw the force of the tragic point of view so clearly that he at times comes close to reinforcing it himself, at least dramatically. Aristotle's position, $I$ have argued, is equivocal, perhaps tantamount, and not only in chapter 14 , to a denial of tragedy's deepest level. Aristotle could not be fully true, I would maintain, both to tragedy and to his own philosophy of man, and I believe that his apparent rapprochement with tragic poetry may finally have to be regarded, against the background of that 'ancient quarrel' which so stimulated Plato, as more of an attempt to woo it over to philosophy's side than to meet it on its own terms. If so, Aristotle was not the last philosopher of whom this could be said.

\section{CORPUS CHRISTI COLLEGE, CAMBRIDGE STEPHEN HALLIWELL}

\section{NOTES}

I am grateful to all those who commented on this paper when it was delivered to the Society, and particularly to Myles Burnyeat for some subsequent criticisms.

1. Plato Rep. 595c, 602b, 605d, 607a, Theaet. 152e, Ar. Poet. 1448b 38-y (where the Odyssey too is included: cf. $\mathrm{n} .45$ below), 1459b 2-4, 7-16. The idea influenced later scholars, as the Homeric scholia show: N. J. Richardson, CQ 30 (1980) 270. 
2. Ch. 25, 1460b 13-15.

3. Cf. p. 57 and n. 31 below on the same word at Phaedo 115a.

4. For a summary of the known plays see G. F. Else, Aristotle's Poetics: the argument (1957) 395-6. On Sophocles' plays of. A. C. Pearson, The fragments of Sophocles I (1917) 91-3, 185-7.

5. 1453a 11 and 21 ; cf. $1454 \mathrm{~b} 23$.

6. Laws 838c 3-7 (for similar language used of tragedy cf. Gorg. 502b). Plato similarly moralises certain tragic myths at Laws $931 \mathrm{~b}-\mathrm{c}$.

7. Rep. 380a-b, where Aeschylean ör $\tau$ is rejected.

8. Rep. $605 \mathrm{c}-\mathrm{d}, 606 \mathrm{~b}, 619 \mathrm{c}$, and cf. $387-8$.

9. For an analysis of the tension see J. Annas, 'Plato's myths of judgement', Phronesis 27 (1982) 131-4.

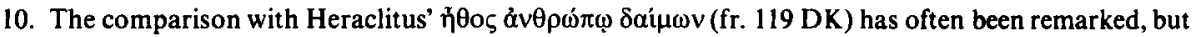
there is a difference between the pointed paradox and Plato's elaborate eschatology. For an interplay of the soul's choice and destiny cf. Laws $903 \mathrm{~b}-5$ d, esp. 904c 6-9.

11. At Phaedo 107d, 108b, 113d Plato keeps to the idea of a daimon allotted to a person. Elsewhere he often uses $\delta \alpha i \mu \omega v$ in traditional senses: e.g. Rep. 468e-9a, Laws 713d, 717b, 730a, 738d etc. On Tim. 90a see E. R. Dodds, The Greeks and the irrational (1951) 213 with n. 31.

12. On these and related terms cf. R. P. Winnington-Ingram, Sophocles: an interpretation (1980) 150-

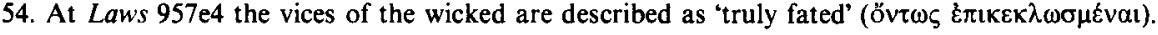

13. See also Il. 3.164, 19.409-10, and $O d .1 .32$, where Aegisthus, like the hasty souls of Rep. 10, ignores a warning: cf. K. J. Dover, JHS 103 (1983) 43.

14. Rep. 378d, 380a-b, 392a-b, (cf. 364), Laws 660e-661 c. Plato believes that the equation between justice and happiness would be worth asserting even as a lie: Law's 663c-d, and the corollary at Rep. 378a.

15. Sympathy for undeserved misfortune is touched on at Laws $936 \mathrm{~b}$, for orphans at $926 \mathrm{e}$, for strangers at $729 \mathrm{e} 6$, for the unjust man (n.b.) at $731 \mathrm{c}-\mathrm{d}$ and Gorg. $469 \mathrm{a}-\mathrm{b}$, and for the prisoners in the cave at Rep. $516 \mathrm{c} 6$. Socrates renounces pleas for pity at Apol. 34-5, tragic pity (cf. Ion $535 \mathrm{~b}-\mathrm{c}$ ) is rejected at Rep. 387d

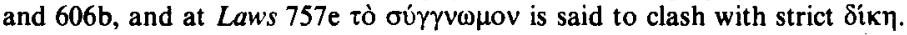

16. If one were looking for consistency, one could say that the hasty soul's tyranny belongs to the fallen

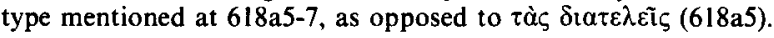

17. Cf. Laws $804 \mathrm{~b}$ with the preceding passage.

18. H. Kuhn, 'The true tragedy: on the relationship between Greek tragedy and Plato', HSCP 52(1941) 12: Plato's objection to mourning is tantamount to a negation of the essence of tragedy. Tragic lament and tragic suffering are ... inseparable'. This has some validity for Greek culture, with its strong emphasis on rituals of mourning, though it would not be universally so. Kuhn's article (with a second, HSCP 53 (1942) 37-88) contains much that is stimulating and germane to my argument, though a great deal is too speculative.

19. See e.g. Epist. 7. 334e, Rep. 585b-d, Laws $959 \mathrm{c}$ (a corpse is $\tau \tilde{\omega} \vee \sigma \alpha \rho \kappa \tilde{v} v$ ö $\gamma \kappa o \zeta$, on which mourning is wasted).

20. Rep. 605-6; 603e refers back to $387-8$. 
21. Esp. $387 \mathrm{e} 9,388 \mathrm{a} 6, \mathrm{~b} 4,605 \mathrm{~d} 1,606 \mathrm{~b} 1$.

22. Rep. 473d-e, 50le, and cf. Epist. 7. 326a-b.

23. Rep. 379d, cf. Laws 906 a.

24. E.g. Laws $873 \mathrm{c}, 924 \mathrm{a}$ and d, ,26e, 928a, 929e, 936b, 944d.

25. The dialogues of Plato ed. 4 (1953) II 406. Kuhn, 25, more aptly calls the Phaedo an 'anti-tragedy', though even this needs qualification.

26. This is not to suggest that pious attempts to assimilate Plato to Christianity, such as that of $G$. Ardley, 'Plato as tragedian', Philosophical Studies 12 (1963) 7-24, are anything but misplaced.

27. Phaedo $88 \mathrm{c}$ : later doubts at $103 \mathrm{c}$ and $107 \mathrm{~b}$.

28. Cf. e.g. Iliad 6.407-13, Soph. O.T. 1071-2, Eurip. Alc. 270-71, Hec. 202-4, 409-14, Tro. 740-41, 761.

29. See Socrates' later explanation of his dismissal of the women, $117 \mathrm{~d}-\mathrm{e}$, with the references at Rep. $387 \mathrm{e}$ and $605 \mathrm{e}$ to giving tragic laments to women. On mourning before death as a bad omen cf. $M$. Alexiou, The ritual lament in Greek tradition (1974) 4-5.

30. Note also the restrictions on mourning at Laws $947 \mathrm{~b}-\mathrm{c}, 959 \mathrm{e}-60 \mathrm{a}$. Socrates' decision to wash his body before death, $116 \mathrm{a}$, is a gesture against a normal funereal procedure: see e.g. $I l$. 18.343-53, 23.41-2, Soph. Antig. 901, El. 1139, O.C. 1602-3. At Phaedo 84e-5a Socrates denies the lamentations of swans, nightingales etc. - common poetic symbols: e.g. Od. 19.518-23, Hesiod W.D. 568-9, Aesch. Agam. 11425, Soph. El. 107, 147-9, 1077, Eurip. El. 151-5, Phaethon 67-70 (Diggle), and cf. the choice of a swan's and nightingale's life by the grieving bards, Orpheus and Thamyras, in the Myth of Er, Rep. 620a.

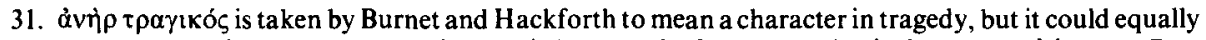

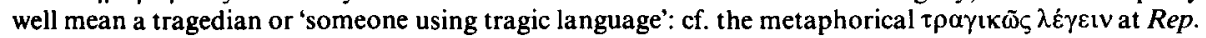

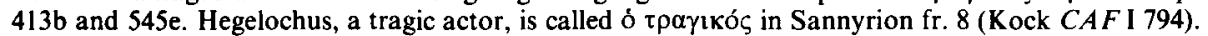
$\varepsilon i \mu \alpha \rho \varepsilon^{\prime} \vee \eta$ in the present passage reinforces my earlier argument that the hasty soul's case in Rep. 10 is intended to carry a tragic echo.

32. Cf. D. Tarrant, 'Plato as dramatist', JHS 75 (1955) 82-9.

33. It should be noted that Phaedo feels no pity but a mixture of pleasure and pain at the start, $58 \mathrm{e}-9 \mathrm{~b}$, yet the effect of the whole dialogue is to elicit his self-pity at the loss of Socrates.

34. The Phaedo's myth contains echoes of Homer: see Burnet's notes on $112 \mathrm{a} 2-4$, e5, 113b3, e2. For the earlier references to $\mu \nu 00 \lambda \circ \gamma$ i $\alpha$ (Plato's standard conception of poetry: $c f . p$. 59 and $n .38$ below) see

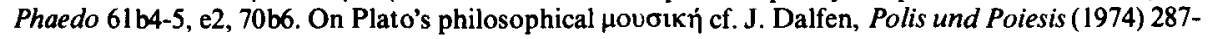
304.

35. In the reference to Ajax there may be a humorous inversion of Odysseus's experience at $\mathrm{Od}$. 11.54364, which is echoed in the Myth of Er, Rep. 620b.

36. This and many other points in the second half of this paper will be dealt with more fully in my forthcoming book on the Poetics.

37. D. W. Lucas, Aristotle: Poetics (1968) 239. Lucas xxii ('nor is he concerned...') offers a representative judgement of the kind which it is my aim to qualify.

38. Cf. n. 34 above, and e.g. Rep. 378e3, 380c2, 392d2, 394b9-10, Laws 941 b-c. 
39. For a concise statement of Aristotle's aesthetic philosophy see M. Hubbard, Ancient literary criticism ed. D. Russell and M. Winterbottom (1972) 86-7.

40. This vacillation has been persistently ignored by interpreters of the Poetics, largely in order to allow to ch. 13, where Aristotle commits himself to the $\delta v \sigma \tau u \chi i \alpha$-ending, more authority than it merits, and to make ch. 14, where the evituxia-ending is advocated, appear more aberrant than it is. Outside these two chapters the relevant passages are: $1451 \mathrm{a} 13-14,1452 \mathrm{a} 22-3,31-2,1452 \mathrm{~b} 2,1455 \mathrm{~b} 28$, in all of which the direction of the change is left open.

41. In fact we would expect some difference in the balance of emotions, since fear specifically concerns prospects: E.N. 1115a9, Rhet. 1382a21. Limited pity too can be felt for the prospective (Rhet. 1382b26, 1386b1), but cf. n. 44 below.

42. I believe that the continuity of premises behind the arguments of chs. 13 and 14 has often been underestimated. This is one, though not the only, reason why I cannot accept the common suggestion that Aristotle's focus changes from the plot-structure as a whole in ch. 13 to the $\pi \dot{\alpha} \theta 0 \varsigma$ as such in ch. 14 .

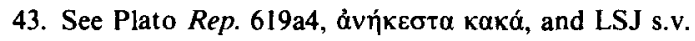

44. At Rhet. 2.8.14-16, 1386a-b, it is claimed that the more close-at-hand $\pi \dot{\alpha} \theta \eta$ are, the more pitiable they become.

45. One need not associate plays such as the I.T. with what Aristotle says in ch. 13, 1453a30-39, and conclude that the former too are quasi-comic. Aristotle thought the 'double' plot too morally comfortable, but his account of plays of averted catastrophe does not put them in this category. Interpretation of the end of ch. 13 is anyway difficult, and complicated by the fact that Aristotle here seems to assimilate the Odyssey to comedy, whereas elsewhere $(1448 \mathrm{~b} 38-9,1451 \mathrm{a} 24-30,1454 \mathrm{~b} 26-30$, 1455a2-4, (?) 1455b16-23, 1459b2-4, 14-15) he tends to treat it, with the Iliad, as quasi-tragic.

46. See esp. E.N. 1.8.15, Rhet. 2.12.2, 2.17.5-6.

47. Ch. 6, 1450a17-20.

48. See esp. E.N. 1.8.15-17 and 1.9.11 for the original acknowledgement, 1.10.9-11 for later misgivings, and 1.10.12-14 for the final concession of the point.

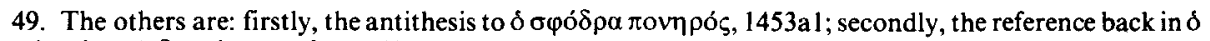
$\mu \eta \tilde{i} \tau \varepsilon \dot{\alpha} \rho \varepsilon \tau \underline{\eta} \delta \imath \alpha \varphi \dot{\varepsilon} \rho \omega \nu \kappa \tau \lambda ., 1453 \mathrm{a} 8$.

50. See E.N. 5.8.7, and cf. T. Stinton CQ 25 (1975) 226.

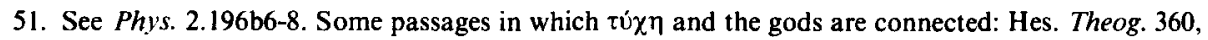
Hom. Hymn 11.5, Pind. Ol. 8.67, 12.1, Pyth. 8.53, Nem. 6.24, fr. 21 (Bowra), Soph. Phil. 1326, Eurip. H.F. 309, 1393, I.A. 1136, Plato Rep. 619c5.

52. I shall argue elsewhere that the principle of 'necessity or probability', on which Aristotle repeatedly insists, is a matter of structural causation, not of mere plausibility, despite a connection with rhetorical عikós.

53. Of the six references to the I.T. (1452b6-8, 1454a7, 1454b3I-5, 1455a18, 1455b3-12, 14-15) only one, the third, contains an element of criticism. The $O . T$. is cited slightly more often (1452a24-6, (?)33, (?)1453b6-7, 31, 1454b7-8, 1455a 18, 1460a29-30, 1462b2-3), but on three occasions (1453b31, 1454b7-8, $1460 \mathrm{a} 29-30$ ) it is noted for a feature less than ideal.

54. Apollo's agency begins before the action of the play, but it is sustained in and through it: cf. I.T.7794, $711-23,936-78,1438$. 
55. The exclusion of $\tau$ ò $\ddot{\alpha} \lambda$ o yov $(1454 \mathrm{~b} 6-7,1460 \mathrm{a} 28-9,1461 \mathrm{~b} 14-15,19-20)$ is the negative counterpart of

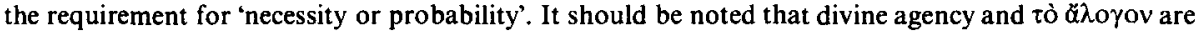
juxtaposed in ch. 15, 1454a37-b8, as comparable defects in what one might call plot-logic.

56. A. MacIntyre, After virtue: a study in moral theory (1981) 153; cf. also 147-8 for some related reflections on tragedy.

57. For some brief but suggestive remarks on the relation between the philosophers' ethics and tragedy's sense of human insecurity, see B. Williams, The legacy of Greece ed. M. I. Finley (1981) 252-3: but when he writes of a sense of significances, found in tragedy, which had 'disappeared ... perhaps altogether from their [the philosophers'] minds', I think Williams overlooks the tensions to be traced precisely in their treatments of tragedy. 